\title{
TECHNO-ECONOMIC AND ENVIRONMENTAL ASSESSMENT OF HYDROGEN PRODUCTION BASED ON NATURAL GAS STEAM REFORMING PROCESS
}

\author{
STEFAN GALUSNYAK, LETITIA PETRESCU, \\ CALIN-CRISTIAN CORMOS ${ }^{a^{*}}$
}

\begin{abstract}
Hydrogen is foreseen as a promising energy vector for the future on the road to develop a low carbon economy. In this respect, developing energy-efficient improved hydrogen production systems with low $\mathrm{CO}_{2}$ emissions is an important aspect. This study is evaluating the most relevant economic and environmental impact elements for hydrogen production based on catalytic natural gas steam reforming. As an illustrative example, an industrial-relevant hydrogen production plant with an output of $50000 \mathrm{Nm} / \mathrm{h}$ was investigated. In addition, a pre-combustion carbon capture feature, based on reactive gas-liquid absorption using alkanolamines (Methyl-DiEthanolAmine - MDEA), was considered to reduce the $\mathrm{CO}_{2}$ emissions. The overall carbon capture rate was $70 \%$. Similar natural gas reforming plant without decarbonization feature is also discussed to quantify the efficiency and economic penalties for $\mathrm{CO}_{2}$ capture. As assessment methods, computational tools, thermal integration analysis and an in-depth techno-economic and environmental procedure were used. For instance, to quantify the overall environmental impact, Life Cycle Assessment (LCA) was used. Various relevant technical, economic and environmental indicators are calculated and discussed in the present work.
\end{abstract}

Keywords: Hydrogen production; Natural gas steam reforming; Carbon capture by chemical scrubbing; Techno-economic and environmental assessment.

\footnotetext{
a Babeş-Bolyai University, Faculty of Chemistry and Chemical Engineering, 11 Arany Janos, RO-400028, Cluj-Napoca, Romania

*Corresponding author: cormos@chem.ubbcluj.ro
} 


\section{INTRODUCTION}

Global warming and climate change are significant challenges of the current time. In an attempt to reduce greenhouse gas emission, low carbon technologies have to be developed and deployed in various industrial sectors [1]. A wide diversity of methods and technologies can be considered to reduce $\mathrm{CO}_{2}$ emissions e.g., large-scale usage of renewable energy sources, carbon capture, utilization and storage (CCUS) options, improving energy conversion, developing new energy carriers with reduced environmental impact [2]. An important element of all new low carbon technologies should be a promising economic impact of the process compared to current stateof-the-art technologies.

Along these important lines, hydrogen is predicted to become an important energy carrier for the future having significant technical, economic and environmental benefits (e.g., high energy conversion efficiency, no greenhouse gas emission when used, lower environmental impact etc.) [3]. Therefore, new developments are expected for the whole hydrogen value chain (production - transport - storage - utilization). Currently, hydrogen is produced from fossil sources (natural gas, oil, coal) with large $\mathrm{CO}_{2}$ emissions and it is mostly used in chemical and petro-chemical sectors as reactant (e.g., ammonia, various hydrogenation processes etc.) as presented in Figure 1 [4].

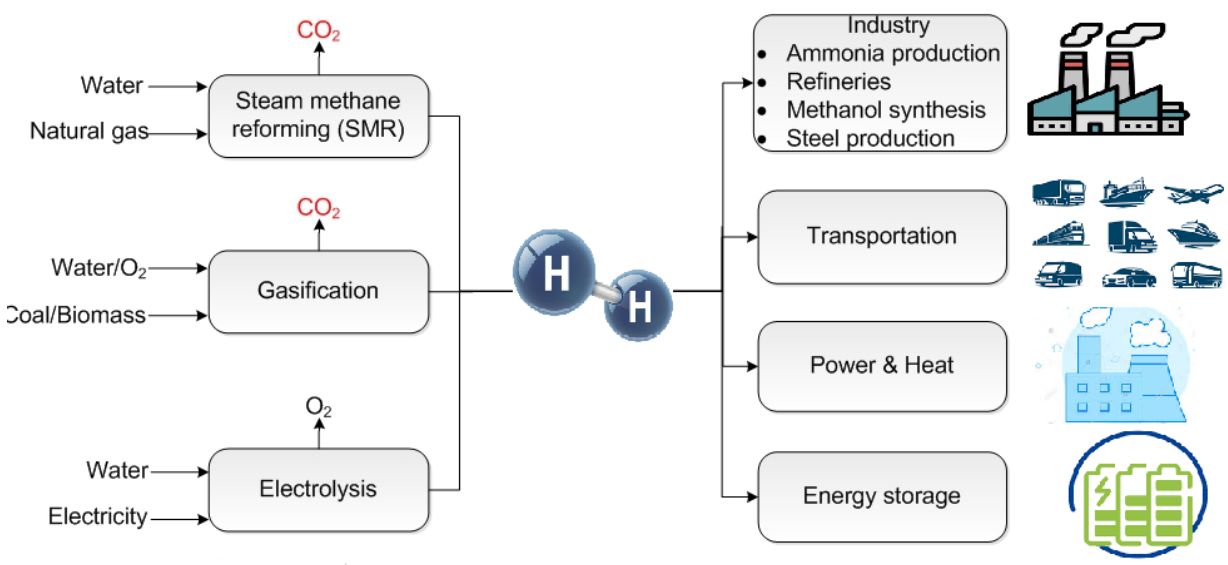

Figure 1. Main hydrogen production routes and applications

This work is aiming to combine the natural gas catalytic steam reforming process (the most used hydrogen production route) with carbon capture feature to significantly reduce the environmental impact of this process. As mentioned before, the new technological concepts must have 
techno-economic and environmental advantages over current technologies. In this respect, this analysis will consider similar hydrogen production route without carbon capture as a benchmark case. As key novelty elements of this work, one can mention the usage of an integrated process modeling thermal integration - techno-economic and environmental assessment methodology to propose improved hydrogen production systems with better performance indicators.

The hydrogen production based on catalytic steam reforming relays of the following reversible chemical reaction:

$$
\mathrm{CH}_{4}+\mathrm{H}_{2} \mathrm{O} \leftrightarrow \mathrm{CO}+3 \mathrm{H}_{2}
$$

The temperature of the natural gas steam reforming reactor is high (around $800-900^{\circ} \mathrm{C}$ ). In addition, the process is highly endothermic, accordingly heat has to be provided. Various configurations can be used, the most important ones are: fired-based reforming reactor (additional natural gas has to be combusted outside of the reactor) and autothermal reforming reactor (heat is generated in-situ using oxygen or air). This work considers the fired-based reforming reactor which has significant benefits than autothermal ones e.g., higher energy efficiency, lower plant complexity, better economics etc. [5-6]. The syngas is then catalytically converted with steam to increase the hydrogen yield and to concentrate the carbon species as $\mathrm{CO}_{2}$ for subsequent capture. The water gas shift (WGS) reaction is the following:

$$
\mathrm{CO}+\mathrm{H}_{2} \mathrm{O} \leftrightarrow \mathrm{CO}_{2}+\mathrm{H}_{2}
$$

As decarbonization technology, the chemical scrubbing using MDEAbased gas-liquid absorption process was considered. This carbon capture method is based on the following chemical reaction [7]:

$$
\mathrm{CO}_{2}+\mathrm{MDEA}+\mathrm{H}_{2} \mathrm{O} \leftrightarrow \mathrm{MDEAH}^{+}+\mathrm{HCO}_{3}{ }^{-}
$$

The captured $\mathrm{CO}_{2}$ is then fed to Carbon Processing Unit (CPU) for drying and compression (up to 120 bar) to satisfy the quality requirements of transport (through pipeline) and storage (e.g., saline aquifers, enhanced oil recovery, depleted oil and gas fields etc.) systems. After decarbonization, the hydrogen rich-gas is purified by Pressure Swing Adsorption (PSA) to the required purity (min. $99.95 \%$ vol. was considered in this analysis) and then compressed to 60 bar for transport. The tail gas is recycled back to the plant (as fuel to reforming reactor). 


\section{PROCESS CONFIGURATION AND MAIN DESIGN ASSUMPTIONS}

The following hydrogen production systems based on natural gas catalytic reforming were investigated in term of main techno-economic and environmental performances:

Case 1: Natural gas steam reforming without carbon capture;

Case 2: Natural gas steam reforming with carbon capture.

The conceptual design of decarbonized hydrogen production route based on catalytic natural gas steam reforming process (Case 2) is presented in Figure 2. Several key technological modifications are present in comparison to the correspondent non-decarbonized design (Case 1): carbon capture unit based on chemical scrubbing, carbon processing unit for drying and compression of captured $\mathrm{CO}_{2}$ stream.

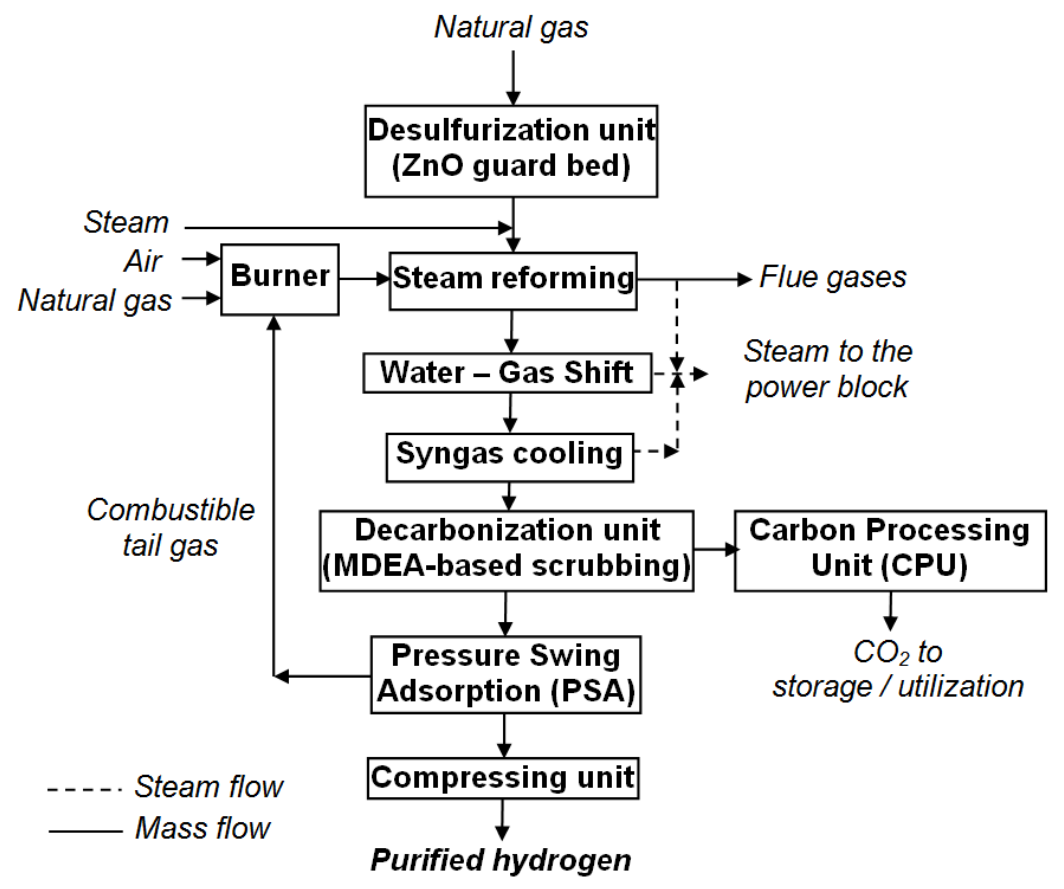

Figure 2. Decarbonized hydrogen production system based on natural gas steam reforming (Case 2)

The evaluated hydrogen production systems based on natural gas catalytic reforming were simulated using ChemCAD software. Table 1 presents the most important modeling assumptions [8-10]. 
TECHNO-ECONOMIC AND ENVIRONMENTAL ASSESSMENT OF HYDROGEN PRODUCTION BASED ON NATURAL GAS STEAM REFORMING PROCESS

Table 1. Main design assumptions

\begin{tabular}{|c|c|}
\hline Process unit & Design parameters \\
\hline Plant capacity \& purity & $\begin{array}{l}\left.50000 \mathrm{Nm}^{3} / \mathrm{h} \text { (equivalent to } 150 \mathrm{MW}_{\mathrm{th}}\right) \\
99.95 \% \text { (vol.) }\end{array}$ \\
\hline Natural gas characteristics & $\begin{array}{l}\text { Composition (\% vol.): } 89 \% \mathrm{CH}_{4}, 7 \% \mathrm{C}_{2} \mathrm{H}_{6}, 1 \% \\
\mathrm{C}_{3} \mathrm{H}_{8}, \quad 0.1 \% \quad \mathrm{C}_{4} \mathrm{H}_{10}, \quad 0.009 \% \quad \mathrm{C}_{5} \mathrm{H}_{12}, \quad 0.001 \% \\
\mathrm{C}_{6} \mathrm{H}_{14}, 2 \% \mathrm{CO}_{2}, 0.89 \% \mathrm{~N}_{2} \\
\text { Lower heating value (LHV): } 46.73 \mathrm{MJ} / \mathrm{kg} \\
\text { Pressure: } 30 \text { bar }\end{array}$ \\
\hline Desulfurization unit & $\begin{array}{l}\text { ZnO guard bed } \\
\text { Sulfur removal yield: }>99 \%\end{array}$ \\
\hline Catalytic reformer unit & $\begin{array}{l}\text { Outlet temperature: } 900^{\circ} \mathrm{C} \\
\text { Gibbs reactor } \\
\text { Thermal mode: heat exchanger } \\
\text { Pressure drop: } 1 \text { bar }\end{array}$ \\
\hline Water Gas Shift (WGS) unit & $\begin{array}{l}\text { Outlet temperature: } 400^{\circ} \mathrm{C} \\
\text { Reactor type: Equilibrium reactor } \\
\text { Thermal mode: adiabatic } \\
\text { Steam to CO ratio: } 2 \text { (molar) } \\
\text { Pressure drop: } 1 \text { bar }\end{array}$ \\
\hline & $\begin{array}{l}\text { Solvent: Methyl-DiEthanol-Amine (MDEA) } \\
\text { Solution concentration: } 50 \% \text { wt. }\end{array}$ \\
\hline Absorption column: & $\begin{array}{l}\text { No. of stages: } 20 \\
\text { Column pressure drop: } 1 \text { bar }\end{array}$ \\
\hline Desorption column: & $\begin{array}{l}\text { No. of stages: } 15 \\
\text { Column pressure drop: } 1 \text { bar } \\
\text { Solvent regeneration with LP steam } \\
\text { Heat duty: } 0.6 \mathrm{MJ} / \mathrm{kg} \mathrm{CO} 2\end{array}$ \\
\hline $\mathrm{CO}_{2}$ processing unit (CPU) & $\begin{array}{l}\text { Drying agent: Tri-Ethylene-Glycol (TEG) } \\
4 \text { stages with inter-cooling } \\
\text { Delivery pressure (at plant gate): } 120 \text { bar } \\
\mathrm{CO}_{2} \text { composition (vol. \%): }>95 \% \mathrm{CO}_{2},<2000 \\
\text { ppm CO, }<250 \mathrm{ppm} \mathrm{H}_{2} \mathrm{O},<100 \mathrm{ppm} \mathrm{H}_{2} \mathrm{~S},<4 \% \\
\text { other gases }\left(\mathrm{N}_{2}, \mathrm{Ar}, \mathrm{H}_{2}\right)\end{array}$ \\
\hline Hydrogen compression unit & $\begin{array}{l}\text { Delivery pressure: } 60 \text { bar } \\
\text { Compressor efficiency: } 80 \% \\
\text { Outlet temperature: } 30-40^{\circ} \mathrm{C}\end{array}$ \\
\hline Heat recovery unit & $\begin{array}{l}\text { Steam conditions: } 480^{\circ} \mathrm{C} \& 48 \text { bar } \\
\text { Steam turbine efficiency: } 85 \% \\
\text { Condensing pressure: } 48 \mathrm{mbar} \\
\text { Cooling water temperature: } 15^{\circ} \mathrm{C}\end{array}$ \\
\hline Heat exchangers & $\begin{array}{l}\Delta \mathrm{T}_{\min .}=10^{\circ} \mathrm{C} ; \\
\text { Pressure drop: } 2-4 \% \text { of inlet pressure }\end{array}$ \\
\hline
\end{tabular}




\section{PROCESS ASSESSMENT METHODOLOGY}

The evaluated cases were simulated using ChemCAD. The thermodynamic package (Soave-Redlich-Kwong - SRK) was selected considering the present chemical species as well as the operational parameters of the processes (e.g., pressure, temperature etc.). For the chemical scrubbing unit, the electrolyte package was used considering the ionic system present in aqueous solution (see reaction 3 ).

The simulation results were compared with experimental / industrial data for model validation [11-12]. No significant differences were observed. For instance, the methane conversion is about $98 \%$ comparable with values from industrial applications. Both hydrogen production designs were optimized in term of energy utilization using pinch method [13]. As an illustrative case, Figure 3 presents the hot and cold composite curves for decarbonized concept (Case 2).

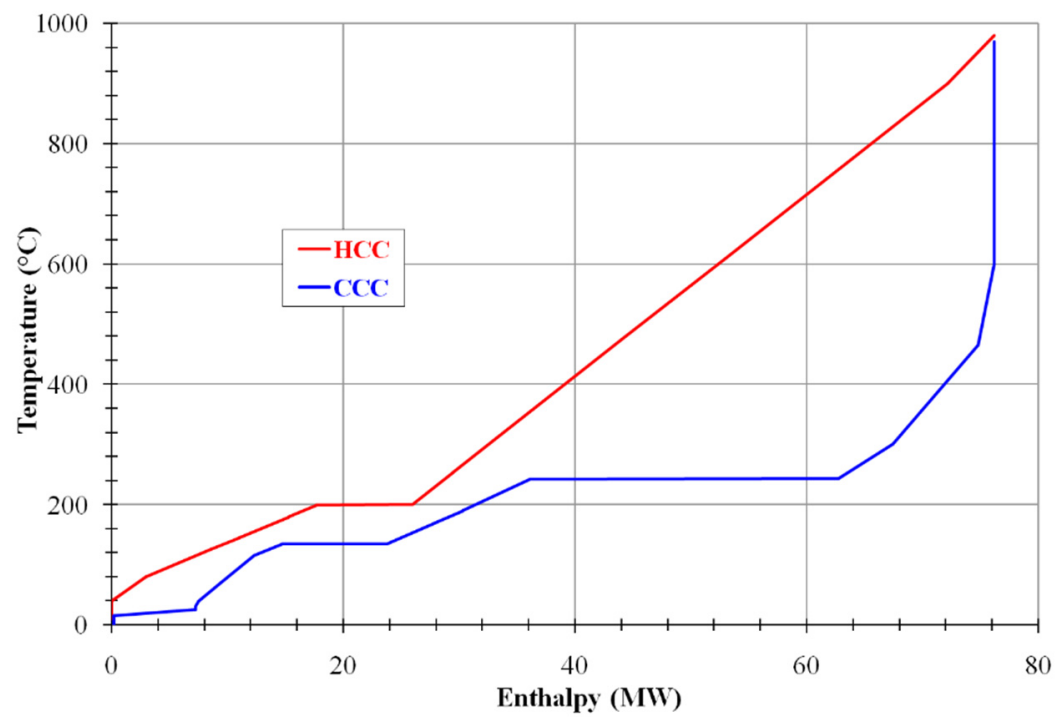

Figure 3. Composite curves for decarbonized hydrogen concept (Case 2)

One can noticed that the available hot streams within the plant (e.g., hot syngas from reforming reactor, shifted gas from WGS reactor, flue gases from reactor burner etc.) are covering the cold stream duties. Even further, an excess heat exists which it is then for steam generation. The generated steam is partly used for catalytic reformer (as reactant) and the rest is expanded in a steam turbine for power generation (to cover the ancillary power consumptions). 
Following the thermal integration analysis, the overall mass and energy balances were then used for the quantification of the overall technoeconomic and environmental performance indicators. The most important performance indexes are presented below:

- Hydrogen and power generation efficiencies $\left(\eta_{\text {Hydrogen }}\right.$ and $\left.\eta_{\text {power }}\right)$ show the overall energy yield of the concepts:

$$
\begin{aligned}
& \eta_{\text {hydrogen }}=\frac{\text { Hydrogen thermal output }}{\text { Natural gas thermal input }} * 100 \\
& \eta_{\text {power }}=\frac{\text { Net power output }}{\text { Natural gas thermal input }} * 100
\end{aligned}
$$

- Plant decarbonization rate $\left(R_{\mathrm{CO}_{2}}\right)$ is quantified as the ratio of captured $\mathrm{CO}_{2}$ molar flow to the input carbon molar flow of natural gas:

$$
R_{\mathrm{CO}_{2}}=\frac{\text { Captured } \mathrm{CO}_{2} \text { molar flow }}{\text { Input carbon molar flow }} * 100
$$

- $\mathrm{CO}_{2}$ emission factor $\left(E_{\mathrm{CO}_{2}}\right)$ is computed considering emitted $\mathrm{CO}_{2}$ mass flow for each MW power plus hydrogen generated within the process:

$$
E_{\mathrm{CO}_{2}}=\frac{\text { Emitted } \mathrm{CO}_{2} \text { mass flow }}{\text { Hydrogen output }+ \text { Net power }} * 100
$$

- Capital cost of a specific plant sub-system $\left(C_{E}\right)$ with a given capacity $(Q)$ is calculated by scalling method using the formula which considers the base cost $\left(C_{B}\right)$ corresponding to the base capacity $\left(Q_{B}\right)$ :

$$
C_{E}=C_{B} *\left(\frac{Q}{Q_{B}}\right)^{M}
$$

- Specific capital investment ( $S C I$ ) is calculated as the ratio of total capital cost and the plant energy output (hydrogen and power):

$$
S C I=\frac{\text { Total capital } \cos t}{\text { Hydrogen output }+ \text { Net power }}
$$


- Levelized cost of hydrogen ( $\mathrm{LCOH})$ is calculated as ratio of annualized capital and operational costs and the plant hydrogen output:

$$
L C O H=\frac{\text { Annualized capital \& operational } \cos t s}{\text { Hydrogen output }+ \text { Net power }}
$$

- $\mathrm{CO}_{2}$ removal and avoided costs is calculated based on levelized cost of hydrogen and $\mathrm{CO}_{2}$ emission factors in both non-decarbonized and decarbonized scenarios:

$$
\begin{gathered}
\mathrm{CO}_{2} \text { removal } \cos t=\frac{\mathrm{LCOH}_{\text {Capture }}-\mathrm{LCOH}_{\text {No capture }}}{\mathrm{CO}_{2} \text { removed }} \\
\mathrm{CO}_{2} \text { avoided } \cos t=\frac{L \mathrm{COH}_{\text {Capture }}-L C \mathrm{CH}_{\text {No capture }}}{E_{\mathrm{CO}_{2} \text { No capture }}-E_{\mathrm{CO}_{2} \text { Capture }}}
\end{gathered}
$$

The main economic assumptions used in the evaluation of hydrogen production systems based on natural gas reforming with and without carbon capture are presented in Table 2 [14-16].

Table 2. Main economic assumptions

\begin{tabular}{|l|c|}
\hline Natural gas cost, $€$ / GJ & 5.0 \\
\hline Boiler feed water $(\mathrm{BFW})$ cost, $€ / \mathrm{t}$ & 0.10 \\
\hline Cooling water $(\mathrm{CW})$ cost, $€ / \mathrm{t}$ & 0.01 \\
\hline $\mathrm{CW}$ treatment cost, $€$ / $\mathrm{m}^{3}$ & 0.0025 \\
\hline BFW treatment cost, $€$ / month & 45000 \\
\hline Personnel number & 78 \\
\hline Direct labour cost, $€$ / person / y & 50000 \\
\hline Administrative costs, \% of direct labour cost & 30 \\
\hline Plant maintenance costs, \% of CAPEX per year & 2.25 \\
\hline Plant capacity factor, \% & 85.62 \\
\hline Internal rate of return, \% & 8 \\
\hline CO 2 storage cost, $€$ / $\mathrm{t}$ & 7 \\
\hline Carbon emission tax, $€ / \mathrm{t}$ & 25 \\
\hline Construction period, years / annual CAPEX share, \% & $2 / 40,60$ \\
\hline Power plant operation life, years & 25 \\
\hline
\end{tabular}

In addition to the global plant environmental indicators (decarbonization rate and $\mathrm{CO}_{2}$ emission factor), an in-depth Life Cycle Analysis (LCA) was performed for the evaluated cases. The LCA analysis considers not only the 
plant but also up-stream (e.g., natural gas, catalysts, solvent chains) and down-stream processes (e.g., $\mathrm{CO} 2$ transport and storage, solvent degradation and disposal). As indicators Global Warming Potential (GWP), Freshwater Eutrophication Potential (FEP), Ozone Depletion Potential (ODP), Fossil fuel Depletion Potential (FDP), Freshwater Ecotoxicity Potential (FETP), Human Toxicity Potential (HTP), Metal Depletion Potential (MDP), Photochemical Oxidant Formation Potential (POFP) and Terrestrial Ecotoxicity Potential (TETP) were considered according to the agreed LCA methodology. The LCA results are reported to $1 \mathrm{MW} \mathrm{H}_{2}$ produced. The full description of the LCA methodology is presented in several different papers of the same authors [17].

\section{RESULTS AND DISCUSSION}

Both hydrogen production cases based on natural gas reforming with and without carbon capture were simulated using ChemCAD software. The mass and energy balances of the evaluated concepts were then used for calculation of main performance indicators. Table 3 presents the most important technical indicators.

Table 3. Key technical performance indicators

\begin{tabular}{|l|c|c|c|}
\hline \multicolumn{1}{|c|}{ Performance indicator } & UM & Case 1 & Case 2 \\
\hline Natural gas flowrate & $\mathrm{t} / \mathrm{h}$ & 15.37 & 15.37 \\
\hline Natural gas LHV & $\mathrm{MJ} / \mathrm{kg}$ & \multicolumn{2}{c|}{46.73} \\
\hline Natural gas thermal energy & $\mathrm{MW}$ th & 203.63 & 203.63 \\
\hline & & & \\
\hline Gross power output & $\mathrm{MW}$ & 8.51 & 5.84 \\
\hline Hydrogen thermal output & $\mathrm{MW}$ th & 150.00 & 150.00 \\
\hline & & & \\
\hline $\mathrm{CO}_{2}$ capture \& compression & $\mathrm{MW}_{\mathrm{e}}$ & 0.00 & 2.12 \\
\hline Hydrogen compression & $\mathrm{MW}$ & 2.09 & 2.09 \\
\hline Power island & $\mathrm{MW}$ & 1.05 & 1.04 \\
\hline Ancillary power consumption & $\mathrm{MW}$ & 3.14 & 5.25 \\
\hline & & & \\
\hline Net power output & $\mathrm{MW}$ & 5.37 & 0.59 \\
\hline Net power efficiency & $\%$ & 2.63 & 0.28 \\
\hline Hydrogen thermal efficiency & $\%$ & 73.66 & 73.66 \\
\hline Cumulative plant energy efficiency & $\%$ & 76.29 & 73.94 \\
\hline Carbon capture rate & $\%$ & 0.00 & 70.00 \\
\hline CO ${ }_{2}$ emissions factor & $\mathrm{kg} / \mathrm{MWh}$ & 267.45 & 82.50 \\
\hline
\end{tabular}


As can be observed from Table 3, the introduction of pre-combustion carbon capture using a MDEA-based gas-liquid absorption unit involves an energy penalty of about 2.34 net percentage points. On the other hand, the $\mathrm{CO}_{2}$ specific emission factor was significantly reduced by about 3.24 times (from 267.45 to $82.50 \mathrm{~kg} / \mathrm{MWh}$ ) corresponding to a plant decarbonization rate of $70 \%$. The main reason that the decarbonization rate is not higher than $70 \%$ represents the unconverted methane and carbon monoxide in reformer and shift reactors [18]. These chemical compounds are not removed by the chemical scrubbing unit being then combusted in the burner to provide the heat duty required by the reforming reaction. For a higher carbon capture $(90 \%)$, a post-combustion capture unit has to be used to capture $\mathrm{CO}_{2}$ from flue gases coming from the reformer burner [19]. This work was not considered an additional post-combustion capture unit due to significant technical elements (increased heat consumption for solvent regeneration) as well as negative influence on economic costs.

Following the technical evaluation of both reforming processes, the next step was to assess the economic performance indicators (e.g., specific investment costs, operational \& maintenance costs, levelized cost of hydrogen, $\mathrm{CO}_{2}$ capture costs). The main economic indicators of hydrogen production concepts based on natural gas reforming with and without decarbonization are presented in Table 4.

Table 4. Key economic performance indicators

\begin{tabular}{|l|c|c|c|}
\hline \multicolumn{1}{|c|}{ Performance indicator } & UM & Case 1 & Case 2 \\
\hline Total installed cost (ex. contingency) & $\mathrm{MM} €$ & 69.30 & 98.91 \\
\hline Total investment cost & $\mathrm{MM} €$ & 83.16 & 118.69 \\
\hline Specific investment cost per kW net & $€ / \mathrm{kW}$ & 535.24 & 788.15 \\
\hline & & & \\
\hline Total fixed O\&M cost (year) & $\mathrm{MM} €$ & 6.73 & 7.06 \\
\hline Total fixed O\&M cost (MWh) & $€ / \mathrm{MWh}$ & 5.78 & 6.25 \\
\hline Total variable O\&M cost (year) & $\mathrm{MM} €$ & 28.73 & 28.50 \\
\hline Total variable O\&M cost (MWh) & $€ / \mathrm{MWh}$ & 24.22 & 25.23 \\
\hline Total fixed and variable costs (year) & $\mathrm{MM} €$ & 34.96 & 35.56 \\
\hline Total fixed and variable costs (MWh) & $€ / \mathrm{MWh}$ & 30.00 & 31.48 \\
\hline & & & \\
\hline Levelized cost of hydrogen $(\mathrm{LCOH})$ & $€ / \mathrm{MWh}$ & 37.57 & 43.03 \\
\hline $\mathrm{CO}_{2}$ removal cost & $€ / \mathrm{t}$ & - & 28.95 \\
\hline $\mathrm{CO}_{2}$ avoided cost & $€ / \mathrm{t}$ & - & 30.71 \\
\hline
\end{tabular}


As can be observed from Table 4, the introduction of pre-combustion carbon capture involves important economic modifications as follows: specific investment cost increases by about $47.25 \%$, the total fixed and variable costs increase by about $5 \%$ and the hydrogen production cost increases by about $14.5 \%$. The $\mathrm{CO} 2$ avoided cost is slightly higher than the current $\mathrm{CO} 2$ emission $\operatorname{tax}(25$ - $28 € / t$ [20]), but the difference is not significant showing the promising perspectives of decarbonization process.

Sensitivity studies (see Figure 4) were performed to see the influence of various key economic elements (e.g., natural gas price, capital and operational costs, internal rate of return, plant availability factor) on hydrogen production cost.

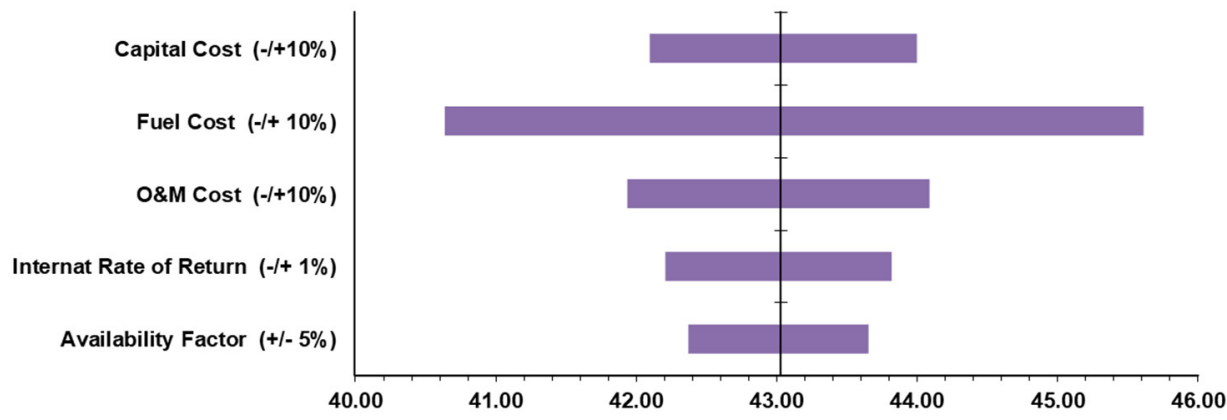

Figure 4. Sensitivity study for decarbonized hydrogen production cost

Finally, an LCA analysis was performed for the investigated cases to determine the most relevant environmental impact indicators. Table 5 presents the key environmental indicators for the evaluated cases.

Table 5. LCA environmental indicators

\begin{tabular}{|c|c|c|c|}
\hline Performance indicator & UM & Case 1 & Case 2 \\
\hline GWP & $\mathrm{kg} \mathrm{CO} 2$ eq. $/ \mathrm{MWh} \mathrm{H}_{2}$ & 278.48 & 101.08 \\
\hline FEP * $10^{5}$ & kg P eq. / MWh H 2 & 39.29 & 40.28 \\
\hline ODP * $10^{9}$ & kg CFC-11 eq. / MWh H & 5.12 & 5.27 \\
\hline FDP & kg oil eq. / MWh $\mathrm{H}_{2}$ & 107.98 & 112.56 \\
\hline FETP * $10^{2}$ & $\mathrm{~kg}$ 1,4-DB eq. / MWh $\mathrm{H}_{2}$ & 5.30 & 5.68 \\
\hline HTP & $\mathrm{kg}$ 1,4-DB eq. / MWh $\mathrm{H}_{2}$ & 3.74 & 4.25 \\
\hline MDP & kg Fe eq. / MWh $\mathrm{H}_{2}$ & 0.53 & 0.64 \\
\hline POFP * $10^{3}$ & $\mathrm{~kg} \mathrm{NMVOC} \mathrm{/} \mathrm{MWh} \mathrm{H}{ }_{2}$ & 11.41 & 48.28 \\
\hline TETP * $10^{3}$ & kg 1,4-DB eq. / MWh H & 0.44 & 0.78 \\
\hline
\end{tabular}


It can be noticed that introduction of carbon capture feature involves a reduction of Global Warming Potential (GWP) by about 2.75 times (from 278.48 to $101.08 \mathrm{~kg} \mathrm{CO}_{2}$ eq./MWh $\mathrm{H}_{2}$ ). The rest of environmental indicators show low to moderate increases (up to 15\%). These can be explained by two main elements: reduction of overall energy efficiency due to carbon capture and usage of additional materials (e.g., chemical solvent) for plant decarbonization. Only Photochemical Oxidant Formation Potential (POFP) shows a significant increase compared to the base case (323\%) due to the influence of chemical solvent (MDEA) production process.

\section{CONCLUSIONS}

This work is evaluating the main techno-economic and environmental performance indicators of decarbonization process for a hydrogen production plant based on natural gas reforming. As the decarbonization technology, the chemical gas-liquid absorption using MDEA was used. A 70\% carbon capture rate was considered for a plant capacity of $50000 \mathrm{Nm}^{3} / \mathrm{h}$ (corresponding to $150 \mathrm{MW}$ hydrogen thermal output). As the results show, the decarbonization process of hydrogen production has a positive influence on key plant performance indicators e.g., low carbon capture energy penalty (about 2.3 net efficiency percentage points), moderate increase of the hydrogen production cost (by about $14.5 \%$ ), attractive $\mathrm{CO}_{2}$ avoidance cost in comparison to the current carbon tax ( 30.7 vs. $25-28 € / t)$ and 2.75 times reduction of global warming potential (assessed by a full LCA analysis). All these promising elements underline the potential of decarbonized hydrogen as a key energy carrier for the future low carbon economy.

\section{ACKNOWLEDGMENTS}

The research leading to these results has received funding from the NO Grants 2014-2021, under Project contract no.13/2020.

\section{REFERENCES}

1. S. Akerboom; W. Botzen; B.A. Michels; M. van Rijswicke; Energy Policy, 2020, 138, 111210

2. C. Ye; Q. Ye; X. Shi; Y. Sun; Energy Policy, 2020, 137, 111094

3. European Commission; $A$ policy framework for climate and energy in the period from 2020 to 2030, 2014, COM (2014) 15 final, Brussels, Belgium 
TECHNO-ECONOMIC AND ENVIRONMENTAL ASSESSMENT OF HYDROGEN PRODUCTION BASED ON NATURAL GAS STEAM REFORMING PROCESS

4. K. Liu; C. Song; V. Subramani; Hydrogen and syngas production and purification technologies, Wiley AICheE, 2010, pp. 1 - 12

5. T. L. Le Valley; A.R. Richard; M. Fan; Int. J. Hydrog. Energy, 2014, 39, 16983-17000

6. F. Dawood; M. Anda; G.M. Shafiullah; Int. J. Hydrog. Energy, 2020, 45, 3847-3869

7. A.L. Kohl; R. Nielsen; Gas purification, Gulf Professional Publishing, 1997, pp. 40 186

8. C.C. Cormos; L. Petrescu; A.M. Cormos; Comput. Aided Chem. Eng., 2014, 33, 1081-1086

9. S. Galusnyak; S. Drăgan; Stud. U. Babes-Bol. Che., 2019, 64, 7-18

10. M. Voldsund; K. Jordal; R. Anantharaman; Int. J. Hydrog. Energy, 2016, 41, 4969-4992

11. International Energy Agency - Greenhouse gas R \& D Programme; Decarbonisation of fossil fuels, 1996

12. K. Aasberg-Petersen; I. Dybkjær; C.V. Ovesen; N.C. Schjødt; J. Sehested; S.G. Thomsen; J. Nat. Gas. Sci. Eng., 2011, 3, 423-459

13. A.M. Cormos; V.C. Sandu; C.C. Cormos; J. Clean. Prod., 2020, 259, 120834

14. M. van der Spek; S. Roussanaly; E. S. Rubin; Int. J. Greenh. Gas Con., 2019, 83, 91-104

15. International Energy Agency - Greenhouse gas R \& D Programme; Techno economic evaluation of SMR based standalone (merchant) hydrogen plant with CCS, 2017

16. D.A. Chisalita; C.C. Cormos; Energy, 2020, 181, 331-344

17. D.A. Chisalita; L. Petrescu; C.C. Cormos; Renew. Sust. Energ. Rev., 2020, 130, 109964

18. K. Atsonios; K.D. Panopoulos; A. Doukelis; A. Koumanakos; Em. Kakaras; Energy Convers. Manag., 2012, 60, 196-203

19. S. Cloete; L. Hirth; Energy, 2020, 192, 116671

20. Sandbag - Smarter Climate Policy; Carbon price viewer, www.sandbag.org.uk/carbon-price-viewer/, 2020 
